\title{
Peningkatan Hasil Belajar Membaca Lancar Melalui Penggunaan Alat Peraga Kartu Huruf Dalam Pelajaran Bahasa Indonesia Pada Siswa Kelas I SDN 05 Nan Sabaris Tahun Pelajaran 2015/2016
}

\section{Erni Mayana}

\begin{abstract}
Learning to write and read at the elementary level is the main staple for Indonesian lessons, if the student does not have the ability to read and write at the beginning of this level, it will be very difficult for any lesson. Result of preliminary observations in primary school 05 Nan Sabaris shows that there are several obstacles facing teachers in the learning process. One problem is difficult to instill the concept of reading and writing to students.

The purpose of this action research are (1) to determine the extent of the use of learning resources in the form of cards letters and syllables and words can affect the ability of students in assembling and read it word for word (2) to improve the ability of students to practice reading by using cards are dealt teacher said. Data were obtained through tests and the use of the observation, the data is processed by a percentage. The results of the analysis of data obtained in the first cycle of learning success; $61.00 \%$, and the second cycle; amounted to $81.50 \%$. So show no increase in student learning from the first cycle to cycle II. Thus the use of the letter cards can increase pemahamn stringing words and read to students. This is evident from the excited students verbatim via encrypted card.
\end{abstract}

Keyword: Increased achievement, use of props such as a letter card

Copyright (C) 2016 IICET (Padang - Indonesia) - All Rights Reserved

Indonesian Institute for Counseling, Education and Theraphy (IICET)

\section{PENDAHULUAN}

Hasil observasi pendahuluan pada siswa kelas I SDN 05 Nan Sabaris, diketahui bahwa guru mengalami kesulitan mengajarkan pengenalan kata-kata yang disusun menjadi kalimat sederhana. Kesulitan ini disebabkan masih banyak kata-kata yang belum dikenal dan kurangnya penggunaan alat peraga. Alat peraga merupakan bantuan yang diperlukan bagi siswa untuk dapat memahami kata-kata yang belum dikenal. Begitu pentingnya alat peraga ini sehingga memudahkan siswa melihat secara nyata kata yang dipelajari. Alat peraga ini cocok digunakan bagi siswa kelas I SD karena cara fikir mereka masih konkret. Salah satu alat peraga yang dapat digunakan untuk siswa adalah kartu huruf. Kartu huruf digunakan untuk mengenalkan kata-kata. Hasil wawancara dengan para guruSDN 05 Nan Sabaris juga diperoleh keterangan bahwa kartu huruf sebaiknya disediakan dengan jumlah yang memadai agar siswa dapat menggunakannya secara maksimal.

Proses pembelajaran dengan menggunakan kartu huruf akan membuat siswa senang. Hal ini disebabkan mereka dapat menyusun kata dan merangkainya menjadi kalimat yang sederhana secara langsung dari kartu huruf yang telah diacak. Menurut Sukmadinata (1988), guru yang baik adalah guru yang dapat mempersiapkan siswa untuk mencapai tujuan pembelajaran sesuai dengan kurikulum yang telah ditetapkan. Mempelajari bahasa Indonesia khususnya merangkai kata diperlukan proses pembelajaran dengan menggunakan pendekatan keterampilan proses dan dibantu dengan alat peraga. Pendekatan keterampilan proses melatih siswa untuk melakukan pengamatan dan mencoba secara langsung. Menurut Funk dan Harlen (1993), keterampilan proses merupakan keterampilan intelektual yang dipergunakan untuk memproses informasi yang diperoleh dalam pembelajaran. Sebagaimana dimuat dalam Depdikbud (1994) bahwa pendekatan keterampilan proses adalah pendekatan dalam proses belajar mengajar yang menekankan kepada pembentukan keterampilan memperoleh dan mengkomunikasikan hasil belajar. Dengan menggunakan pendekatan keterampilan proses, diharapkan siswa mencapai hasil belajar sesuai dengan tujuan kurikulum. Tujuan kurikulum meliputi aspek pengetahuan (cognitive domain), aspek sikap (affective domain), dan aspek keterampilan (psychomotor domain) (Darmodjo dan Kaligis, 1992).

Penelitian Sarjono (2000) menyatakan bahwa jika penerapan keterampilan proses siswa sangat kurang maka siswa menunjukkan ketidakmampuan mengekspresikan ide-ide dengan caramereka sendiri. Berdasarkan 
gejala-gejala tersebut di atas, diperlukan peningkatan aktifitas membaca secara rutin dan berkelanjutan dengan menggunakan alat peraga yang memadai bagi siswa. Pelaksanaan membaca dalam pembelajaran dapat dilakukan di ruang perpustakaan agar lebih leluasa untuk menyusun dan merangkai kata menjadi kalimat sederhana. Membaca merupakan suatu proses menyusun huruf demi huruf yang bermakna, yang kemudian bisa dilukiskan lambang-lambang grafik yang menggambarkan suatu bahasa yang dapat dipahami orang lain (Sumanto,1987: 21). Wardana (1990:15) berpendapat bahwa "membaca adalah keseluruhan rangkaian kegiatan seseorang dalam menyebutkan simbol yang tertulis dalam bahasa tulis yang mempunyai arti sesuai dengan lambang atau huruf yang ditulis, sehingga seseorang akan bisa menangkap makna dari apa yang tertera". Selanjutnya, Lado (1964:143) menjelaskan tentang menulis, bahwa, "menulis adalah menyusun tanda-tanda tulis (graph symbols) yang menyatakan suatu bahasa yang diketahui oleh seseorang sehingga orang lain dapat membaca tanda-tanda tulis itu jika mereka mengenalnya dan mengerti bahasanya". Ahli lain, Hearton dalam Diknas (2007:3) mengungkapkan bahwa,

“ Menulis adalah kegiatan menyusun kata-kata menjadi kalimat secara benar sesuai dengan

kaidah tata bahasa, kemudian menghubung-hubungkan kalimat tersebut sehingga berbentuk

suatu tulisan yang saling berhubungan yang dapat mengkomunikasikan pikiran dan ide penulis

tentang suatu topik tertentu".

Byrne dalam Diknas (2007:3) menguraikan bahwa "menulis tidak hanya membuat satu kalimat atau beberapa kalimat yang berhubungan, tetapi menghasilkan serangkaian kalimat yang teratur yang berhubungan satu dengan yang lain dan dalam gaya tertentu". Berdasarkan pendapat-pendapat di atas dapat disimpulkan bahwa membaca dan menulis adalah kegiatan menyusun kata-kata.

Masalah dalam penelitian dirumuskan sebagai berikut: (1) Pada kelas awal permulaan belajar membaca dengan mengenal huruf (2) Penggunaan metode pembelajaran membaca selama ini kurang membantu siswa dengan cepat mengenal huruf sehingga menyulitkan siswa untuk membaca. Rumusan masalah penelitian adalah (1) Bagaimanakah upaya meningkatkan kemampuan membaca bagi kelas permulaan di SDN 05 Nan Sabaris? (2) Apakah dengan menggunakan alat peraga berupa kartu huruf-huruf yang bisa diacak kemudian disusun untuk menjadi sebuah kata yang bermakna dapat meningkatkan kemampuan siswa membaca?

\section{METODOLOGI PENELITIAN}

Penelitian ini adalah penelitian tindakan kelas (classroom action research). Lewin (dalam Kemmins dan McTaggart, 1988) mendeskripsikan Penelitian Tindakan Kelas sebagai tindakan berkelanjutan dari langkah-langkah berbentuk spiral. Setiap langkah (siklus) berisi perencanaan, pelaksanaan tindakan, observasi (evaluasi), dan refleksi tindakan.Penelitian ini berlangsung 2 siklus, setiap siklus terdiri atas 4 tahap, yaitu (1) tahap perencanaan, meliputi : pembekalan kepada guru, penyusunan model pembelajaran, penyiapan instrumen tes (pretes, postes), lembar observasi dan membentuk kelompok belajar siswa, (2) tahap pelaksanaan tindakan, meliputi: pelaksanaan kegiatan dari perencanaan yang dibuat, (3) tahap observasi, yaitu pengamatan dari pelaksanaan tindakan melalui pedoman observasi, dan (4) tahap refleksi, yaitu menganalisis dan memberi pemaknaan dari pelaksanaan tindakan, sehingga dapat dibuat perencanaan tindakan pada siklus berikutnya.

\section{HASIL DAN PEMBAHASAN PENELITIAN}

\section{A. Hasil Penelitian}

Siklus I dilaksanakan 2 kali pertemuan dengan materi membahas kartu kata yang akan disusun menjadi sebuah kalimat sederhana. Masing-masing pertemuan memerlukan waktu 3 x 35 menit. Pembagian waktunya 15 menit motivasi awal dari guru dan pembagian kelompok, 70 menit kegiatan di kelas serta presentasi dan menunjukkan kemampuan merangkai kata dan membaca di depan kelas selama 20 menit kemudian di akhiri dengan rangkuman oleh guru. Setiap siklus diawali dengan pre-tes dan pada akhir siklus diadakan post-tes. Hasil pengamatan pada siklus I adalah sebagai berikut, yakni (a) guru telah memulai pelajaran dengan memberi motivasi pada siswa dan mengakhiri dengan membuat rangkuman, (b) pada setiap kegiatan, guru telah berusaha mendampingi siswa, (c) kegiatan diskusi siswa masih kurang aktif terutama kelompok 2 \& 4 dan yang aktif kelompok $1 \& 3$ (d) dari hasil post-tes, siswa yang telah tuntas 7 orang dan 13 orang yang belum tuntas. Hasil refleksi pada siklus I adalah (a) keaktifan siswa dalam kerja kelompok kurang, (b) siswa belum mampu merangkai suku kata menjadi kalimat sederhana, (c) guru mendorong siswa berani mengajukan dan menjawab pertanyaan, (d) terdapat 35\% siswa telah tuntas, dan $65 \%$ siswa belum tuntas.Refleksi daritindakan pada siklus I disusun rencana tindakan siklus II sebagai berikut: yakni (1) guru merubah susunan kelompok dengan memasukkan siswa yang kurang berhasil menjadi 2 kelompok (kelompok I dan kelompok 2), (2) memasukkan siswa yang belum tuntas ke dalam 2 kelompok tadi, (3) guru harus lebih memfokuskan 
perhatian kepada siswa yang belum tuntas, (4) guru menyarankan siswa bekerja lebih sistematis, dan (5) siswa diwajibkan mengenal suku kata yang akan dirangkai menjadi kata, sehari sebelumnya.

Siklus II dilaksanakan 3 kali pertemuan, masing-masing 3 × 35 menit. Materi yang dibahas adalah kartu yang terdapat di depan siswa yang sudah dibagikan perkelompok belajar dan menyusun kegiatan yang meliputi: Pembagian waktu dan teknik pelaksanaannya secara umum sama dengan siklus I. Hasil pengamatan tindakan pada siklus II adalah sebagai berikut: yakni (a) guru melaksanakan proses pembelajaran dengan baik, (b) kerja kelompok siswa berjalan dengan baik, (c) siswa aktif menyusun kata menjadi kalimat dan membacanya dengan benar, (d) aktivitas kelompok yang menjadi fokus penelitian berjalan dengan baik dan aktif, (e) dari hasil post-tes terdapat $90 \%$ (18 orang yang telah tuntas), sedangkan 2 orang belum tuntas belajar. Refleksi tindakan pada siklus II sebagai berikut: (a) kerja sama kelompok dan keaktifan berjalan dengan baik, (b) kelompok yang menjadi fokus penelitian mampu meningkatkan kemampuan membacanya terhadap kata-kata acak yang disusun menjadi kalimat sederhana, (c) tingkat ketuntasan belajar secara klasikal mencapai $90 \%$ atas banyak 18 orang, berarti sudah berada di atas $80 \%$, dan (d) pelaksanaan siklus berikutnya tidak diperlukan lagi.

Hasil pembelajaran dari kedua siklus diperoleh hasil secara berturut-turut yaitu (a) $35 \%$ pada siklus I, (b) $90 \%$ pada siklus II. Artinya ada peningkatan hasil belajar membaca yang dikuasai oleh siswa kelas I SDN 05 Nan Sabaris dalam proses pembelajaran Bahasa Indonesia.

\section{B. Pembahasan}

Penggunaan alat peraga berupa kartu hurufdalam mata pelajaran Bahasa Indonesia dapat meningkatkan kemampuan merangkai kata dan membaca pada siswa. Hal ini telah terbukti dari hasil pelaksanaan tindakan pada setiap siklus. Peningkatan kemampuan membaca siswa di dukung oleh penggunaan alat peraga dalam proses pembelajaran karena dapat mempercepat pemahaman siswa untuk mengenal dan merangkai kata serta membaca pada kelas I SDN 05 Nan Sabaris. Temuan ini sesuai dengan pendapat Arief (1996) yang menyatakan penggunaan media dalam bentuk asli akan lebih bermakna bagi anak didik dan bagi pengembangan ilmu pengetahuan alam dibandingkan media bentuk model, gambar, dan sketsa.

Bila dibandingkan dengan temuan peneliti lain yang dirujuk, maka penelitian ini mempunyai karakteristik tersendiri, yaitu pemanfaatan kartu-kartu huruf, suku kata dan kata yang dibuat dan ditulis pada karton yang ada di lingkungan sekolah dalam upaya mempercepat pemahaman tentang bacaan dari kata yang disusun siswa. Hasil penelitian ini bermanfaat bagi siswa, seperti (1) siswa memiliki keterampilan untuk mendapatkan ilmu yang berupa "keterampilan proses" atau metode ilmiah, (2) gairah belajar siswa meningkat, tercermin dari keaktifan siswa dalam melakukan kegiatan menyusun kata yang diacak di sekolah, dan (3) belajar menjadi bermakna, karena setelah konsepnya dipahami maka konsep tersebut lebih lama dapat diingat. Temuan ini didukung oleh pendapat Arikunto (1990) bahwa lingkungan sekolah merupakan sesuatu yang dekat dengan dunia siswa dan mudah dikenal dalam kehidupan sehari-hari, serta lingkungan sekolah merupakan tempat yang menunjang sebagian dari kebutuhan siswa.

Penelitian ini juga berguna bagi guru, karena (1) guru dapat memperdalam pendekatan dan metode yang digunakan, (2) guru menjadi lebih profesional, karena meningkatnya pengetahuan dan pemahaman tentang penelitian tindakan kelas. Temuan ini didukung oleh Susilo (2000) menyatakan bahwa guru yang terampil melaksanakan PTK adalah guru yang selalu mau meningkatkan proses pembelajaran yang dikelolanya.Implikasi penelitian ini bagi sekolah adalah sekolah memiliki guru yang profesional dan sekolah dapat menambah koleksi tumbuhan yang berguna dalam proses pembelajaran, keindahan, kesejukan, dan pelestarian lingkungan. Tidak kalah penting artinya temuan ini bagi peneliti karena (1) dapat meningkatkan pengetahuan tentang PTK, (2) mengenal lebih dalam mata pelajaran Bahasa Indonesia di SD, dan (3) dapat merintis kerja sama kemitraan dengan sekolah dan guru.

Penggunaan alat peraga dapat meningkatkan kemampuan siswa dalam mengerjakan LKS secara berkelompok. Hal ini dapat terwujud karena pada setiap pelaksanaan tindakan, guru selalu membentuk kelompok-kelompok yang terdiri atas lima sampai enam orang siswa, baru kemudian dibagikan kartu huruf. Kelompok ini tidak selalu tetap, karena pada setiap siklus selalu berubah susunan anggotanya. Perubahan ini bertujuan (a) memudahkan guru membimbing siswa, (b) membiasakan siswa bekerja secara berkelompok pada setiap orang, dan (c) meningkatkan keaktifan berdiskusi dengan susunan baru, serta siswa akan lebih bergairah belajar.

Pada siklus I ada dua kelompok yang belum aktif seperti kelompok 2 \&4. Dari hasil pengamatan menunjukkan bahwa kelompok ini belum aktif untuk menyusun kata dari kartu huruf, belum dapat menyelesaikan tugas dengan tuntas dan belum mampu membuat kesimpulan dengan benar. Dentsch (dalam Lazarowith dan Slavin, 1984) menyatakan agar pembelajaran dapat berlangsung secara kerja kelompok, maka siswa harus mempersiapkan diri saling tergantung secara positif antara anggota kelompok lain. 
Pada siklus II dengan diadakan perubahan susunan kelompok dan fokus guru lebih diarahkan kepada kelompok yang kurang tuntas, ternyata dapat meningkatkan aktivitas kelompok menjadi lebih baik dan aktif. Kenyataan ini terlihat pada (a) masing-masing mampu menyelesaikan tugasnya, dan (b) siswa telah berani mengajukan tampil untuk menyusun kata kemudian membacanya secara lantang di depan kelas memperesentasikan hasil temuannya. Hal ini menunjukkan kerja sama kelompok dapat dibangun dari kesadaran masing-masing individu dalam kelompok. Temuan ini didukung pendapat Slavin (1986) bahwa ciri khusus yang membentuk belajar kelompok adalah metode ini mendorong siswa bekerja sama untuk belajar dan bertanggung jawab. Dengan hasil tersebut berarti penggunaan alat peraga dapat meningkatkan kemampuan siswa membaca dan mengerjakan tugas secara berkelompok ataupun perorangan berada dalam kategori baik.

\section{KESIMPULAN DAN SARAN}

KESIMPULAN

Berdasarkan hasil penelitian dan pembahasan dapat disimpulkan sebagai berikut.

1. Penggunaan alat peraga berupa kartu huruf dalam proses pembelajaran dapat meningkatkan kemampuan membaca siswa. Hal ini dibuktikan dengan terjadinya peningkatan ketuntasan belajar siswa pada setiap siklus.

2. Kerja sama kelompok semakin meningkat pada setiap siklus. Keberhasilan ini ditunjukkan dengan aktifnya siswa dalam diskusi kelompok dan diskusi kelas, sehingga pembelajaran menjadi lebih bermakna bagi siswa.

\section{SARAN}

Berdasarkan kesimpulan di atas, dapat disarankan sebagai berikut.

1. Agar guru dapat menggunakan alat peraga yang sesuai dengan materi ajar. Alat peraga yang digunakan sebaiknya sesuai dengan lingkungan (konstektual).

2. Agar kepala sekolah menyarankan kepada untuk menggunakan berbagai alat peraga secara kontekstual

3. Agar guru/peneliti lain melanjutkan penelitian ini dengan menggunakan alat peraga yang lain.

\section{DAFTAR PUSTAKA}

Arikunto, Suharsimi dkk. 2006. Penelitian Tindakan Kelas. Jakarta: Bumi Aksara

Atmazaki. 2006. Kiat-kiat Menyorong dan Penyunting. Padang: Citra Budaya

Bahri, Syaiful dan Aswan Zain. 1995. Strategi Belajar Mengajar. Banjarmasin: Rineka Cipta

Diknas. 2003. Kurikulum 2004 Sekolah Menengah Pertama (SMP) Mata Pelajarn Bahasa dan Sastra Indonesia. Jakarta: Diknas

Endraswara, Suwardi. 2005. Metode dan Teori Pengajaran Sastra. Yogyakarta: Buana Pustaka

Muhardi dan Hasanuddin W.S. 2006. Prosedur Analisis Fiksi :Kajian Strukturalisme. Padang: Citra Budaya

Rusyam, A. Tabrani. dkk. 1992.Pendekatan Dalam Proses Belajar Mengajar. Bandung: PT. Remaja Rosdakarya

Sudjana, Nana dan Ahmad Rivai. 1990. Media Pengajaran, (Penggunaan dan Pembuatannya). Bandung: CV Sinar Baru

Suyatno. 2004. Teknik Pembelajaran Bahasa dan Sastra. Surabaya: Penerbit SIC 